ment (7-9) there exists an equalibrium between acetylcholine and catecholamine content of the heart under various experimental conditions. Hence, the increase in acetylcholine level of the heart as observed in the present study may be of a compensatory nature of the clevation of noradrenaline content, of hearts from thyroxine treated animals, as already reported (1). Further, Burn (10) has suggested that the amount of acetylcholine formed in the heart is proportional to its beat rate. Since it is well known that thyroxine increases heart rate $(11,12)$, this factor may also play a role in causing an increase in atrial and ventricular acetylcholine.

Greatful acknowledgement is made to Glaxo Laboratories (India) Pvt. Ltd., for generous supply of 1-thyroxine sodium powder.

\title{
REFERENCES
}

1) Lee, W.C., Lef, C.Y. And Yoo, C.S.: Br. J. Pharmac. Chemother. 25, 651 (1965); 2) Kinguit, R.T.: Anesthesiology 6, 225 (1945); 3) Brewster, W.R., IsAacs, J.P., Osgood, P.F. And King, T.L.: Circulation 13, 1 (1956); 4) Bülerivg, E. ANd Burn, J.H.: J. Physiol. 108, 508 (1949); 5) JoKEL, E.: Heart and Sport 58 Charles S. Thomas, Springfield Illinois (1964); 6) Anand, B.K.: Am. J. Physiol. 168, 218 (1952); 7) Sharma, V.N. and Barar, F.S.K.: Ind. J. Med. Res. 54, 102 (1966); 8) Sharma, V.N. and Parmar, N.S.: Ind. J. Med. Res. 55, 60 (1967); 9) Khanna, N.K. and Madan, B.R.: Arch. int. Pharmacodyr. Thér. 175, 136 (1968); 10) Burn, J.H.: Am. Rev. Pharmac. 9, 1 (1969); 11) Hirvonen, L. And L Lybiacil, H.: Am. J. Physiol. 36, 23 (1956); 12) Thier, M.D., Gravinstein, J.S. and Hoffmann, R.G.: J. Pharmac. exp. Ther. 136, 133 (1962)

\section{NEUROPHARMACOLOGICAL ACTIONS OF TWO NEW ADRENERGIC BETA-RECEPTOR ANTAGONISTS, BUNOLOL AND H 64/52}

\author{
N.K. KHANNA, * R.S. GUPTA, A.K. MATHUR and K. GUPTA \\ Department of Pharmacology and Experimental Therapeutics, \\ Dr. S.N. Medical College, Jodhpur, Rajasthan, India
}

Received for publication November 22, 1971

Some of the beta-adrenergic blocking agents possess marked central nervous depressant and anticonvulsant properties $(1,2)$ while the others induce central nervous stimulation (2). For this reason neuropharmacological actions of two new beta-adrenergic blocking drugs, bunolol (d1-5-[3-(tert-butylamino)-2-hydroxypropoxy]-3,4-dihydro-1-(2H)-naphthalenone hydrochloride) and H 64/52 (p-allyl-phenoxypropanolamine) have been studied as follows:

1) Spontaneous motor activity (SMA): The method described by Vad et al. (3) was employed except for slight modification (4). Twenty-four albino rats of both sexes weighing

* Present addrcss: Department of Pharmacology and Experimental Therapeutics, S.P. Medical College, Bikaner, Rajasthan, India. 
TABLE 1. Effect of bunolol and $\mathrm{H} 64 / 52$ on SMA of rats.

\begin{tabular}{|c|c|c|c|}
\hline Drugs and doses & $\begin{array}{c}\text { SMA } 30 \text { min } \\
\text { before drug } \\
\text { treatment (mean) }\end{array}$ & $\begin{array}{l}\text { SMA } 15 \mathrm{~min} \\
\text { after drug } \\
\text { treatment } \\
\text { (mcan) }\end{array}$ & $\begin{array}{c}\text { Percentage } \\
\text { change* } \\
\text { (mean } \pm \text { S.E.) }\end{array}$ \\
\hline $\begin{array}{l}\text { Bunolol } \\
\text { (1 mg/kg i.p.) }\end{array}$ & 1986 & 766 & $61.4 !-10.7$ \\
\hline $\begin{array}{l}\text { H } 64 / 52 \\
(5 \mathrm{mg} / \mathrm{kg} \text { i.p. })\end{array}$ & 1397 & 665 & $52.4 \doteq 10.0$ \\
\hline $\begin{array}{l}\text { Amphetanine : Bunolol } \\
(5 \mathrm{mg} / \mathrm{kg} \text { i.p. }) \quad(1 \mathrm{mg} / \mathrm{kg} \text { i.p. })\end{array}$ & 6662 & 4295 & $35.5 \pm 8.8$ \\
\hline $\begin{array}{l}\text { Amphetamine }+\mathrm{H} 64 / 52 \\
(5 \mathrm{mg} / \mathrm{kg} \mathrm{i.p.})(5 \mathrm{mg} / \mathrm{kg} \mathrm{i.p.})\end{array}$ & 5513 & 6830 & $23.9 \pm 2.7$ \\
\hline
\end{tabular}

There were 6 animals per group.

* There was SMA reduction in all the groups except

No. 4 which showed an increese.

between $100 \mathrm{~g}$ and $250 \mathrm{~g}$ were used, with one rat being tested at a time. Drugs were administered intraperitoneally as in Table 1.

2) Penfobarbitone-induced hypnosis: Thirty mice of both sexes weighing between $25 \mathrm{~g}$ and $35 \mathrm{~g}$ were divided into three equal groups. The first group was treated with saline. Second and third groups were treated with bunolol and $\mathrm{H} 64 / 52$ in doses of $1 \mathrm{mg} / \mathrm{kg}$ and $10 \mathrm{mg} / \mathrm{kg}$ respectivcly. After $15 \mathrm{~min}$ all three groups were treated with pentobarbitone sodium at a dose of $40 \mathrm{mg} / \mathrm{kg}$. When the animals lost righting reflex they were kept on their backs. Regain of righting reflex and mobilization was recorded.

3) Maximal clectroshock seizures: Seizures were produced in albino rats weighing betwecn $100 \mathrm{~g}$ and $150 \mathrm{~g}$ according to the method of Hendley et al. (5). The shocks (150 mA, $0.2 \mathrm{sec}$ and 60 cycle A.C.) were administrated through ear electrodes. Prevention of the extensor tonic spasm and death was accepted as criterion for protection. Three groups of animals were employed, with one group serving as control. Bunolol in a dose of 10 $\mathrm{mg} / \mathrm{kg}$ and $64 / 52$ in a dose of $20 \mathrm{mg} / \mathrm{kg}$ wcre administered intraperitoneally to the second and third group respectively. After $30 \mathrm{~min}$, drug treated animals were exposed to shock.

Doses used in the present study were selected for each experiment after performing preliminary experiments in doses ranging from $0.03 \mathrm{mg} / \mathrm{kg}$ to $15.0 \mathrm{mg} / \mathrm{kg}$ with bunolol and from $0.1 \mathrm{mg} / \mathrm{kg}$ to $20 \mathrm{mg} / \mathrm{kg}$ with $\mathrm{H} 64 / 52$.

The present series of experiments show that bunolol and $\mathrm{H} 64 / 52$ cause a significant reduction in SMA (Table 1). In this respect they resemble such beta-adrenergic blocking drugs as propranolol, pronethanol and idrobutamine $(1,2,6)$. Further, the potentiating effect of $H$ 64/52 on the hyperactivity of d-amphetamine is to be expected as such effects have been observed with other drugs like reserpine $(7,8)$ which is known to reduce SMA. The bunolol and $\mathrm{H} \mathrm{64/52}$ have no sedative or hypnotic action of their own, though they have significantly potentiated the hypnotic action of pentobarbitone. For this reason, they resemble $\mathrm{H} 56 / 28, \mathrm{Ph}$ QA33 and propranolol (9) which have been demonstrated to potentiate barbiturate-induced sleep in mice, however they are unlike INPEA which has no such effect on pentobarbital-induced sleep (9). As an anticonvulsant, H 64/52 is more potent than 
TABLE 2. Effect of bunolol and $\mathrm{H} \mathrm{64/52}$ on electrically induced motor seizures in rats.

\begin{tabular}{lccccc}
\hline Drug and dose & $\begin{array}{c}\text { Number } \\
\text { of } \\
\text { animals }\end{array}$ & $\begin{array}{c}\text { Number of animals } \\
\text { showing extensor } \\
\text { tonic spasm }\end{array}$ & $\begin{array}{c}\text { Mean duration } \\
\text { of extensor } \\
\text { tonic spasm } \\
\text { in sec }\end{array}$ & $\begin{array}{c}\text { Mean duration } \\
\text { of stupor in } \\
\text { min }\end{array}$ & $\begin{array}{c}\text { Number of } \\
\text { deaths in } \\
24 \mathrm{hr}\end{array}$ \\
\hdashline $\begin{array}{l}\text { Contol } \\
\text { (no drug) }\end{array}$ & 20 & 20 & 8.0 & 21.6 & 0 \\
$\begin{array}{l}\text { Bunolol } \\
(10 \mathrm{mg} / \mathrm{kg} \text { i.p. })\end{array}$ & 10 & 8 & 2.6 & 27.0 & 0 \\
$\begin{array}{l}\mathrm{H} 64 / 52 \\
(20 \mathrm{mg} / \mathrm{kg} \text { i.p.) }\end{array}$ & 10 & 4 & 2.5 & 15.2 & 0 \\
\hline
\end{tabular}

bunolol. Bunolol only protected $20 \%$ of the animals against electroconvulsive shock while H 64/52 protected $60 \%$ (Table 2). Similar property has also been observed with other beta-adrenergic-blocking drugs like propranolol, pronethalol and idrobutamine $(1,2)$ It therefore appears that bunolol and $\mathrm{H} 64 / 52$ belong to the group of beta-adrenergic-blocking drugs which depress the central nervous system and have anticonvulsant properties.

dl-Bunolol was supplied by Warner Lambert Research Institute, Marris Plains, New Jersey and $H$ 64/52 by Hässle, Sweden.

\title{
REFERENCES
}

1) Leszkoveszky, G. And Tardos, L.: J. Pharm. Pharmac. 17, 518 (1965); 2) Murmann, W., Almiravta, L. and Saccani-Gutlfi, M.: J. Pharm. Pharmac. 18, 317 (1966); 3) Vad, B.G., Snortri, D.S. and Balwani, J.H.: Ind. J. Physiol. Pharmac. 7, 153 (1963); 4) Pendse, V.K. And Madan, B.R.: Ind. J. Physiol. Pharmac. 13, 29 (1969); 5) Hendley, C.D., Daye Davenport, H.W. and Toman, J.E.P.: Am. J. Physiol. 153, 580 (1948); 6) Estlle, C.J.: J. Pharm. Pharmac. 23, 714 (1971); 7) SмIтн, C.B.: J. Pharmac. exp. Ther. 142, 243 (1963); 8) Stolk, J.M. And Richi, R.H.: J. Pharmac. exp. Ther. 158, 140 (1967); 9) Hermansev, K.: Acta Pharmac. Toxic. 27, 453 (1969).

\section{CENTRAL ACTIONS OF METHOTRIMEPRAZINE (LEVOMEPROMAZINE) AS AN ANALGESIC REPORT 1. DEPRESSANT ACTION ON EEG AROUSAL RESPONSE INDUCED BY DIFFERENT SENSORY STIMULATIONS}

\author{
Hiroshi KUROMI, Masamichi SATOH and Hiroshi TAKAGI \\ Depatment of Pharmacology, Faculty of Pharmaceutical Sciences, \\ Kyoto University, Sakyo-ku, Kyoto, Japan
}

Received for publication December 1, 1971

It has been reported that methotrimeprazine (levomepromazine), a phenothiazine derivative, possesses analgesic property in both clinical (1-3) and pharmacological tests(4). Sites and mechanisms of analgesic action of methotrimeprazine have not yet been clarified. 